\title{
MENU ENGINEERING SEBAGAI STRATEGI PENETAPAN PRODUK MAKANAN DALAM MENGHADAPI TATANAN KEHIDUPAN BARU DI KORI RESTAURANT \& BAR KUTA - BALI
}

\author{
Bagus Putu Ekadharma Susila ${ }^{1}$ \\ Surya Nugraha ${ }^{2}$
}

Akademi Komunitas Mapindo Bali ${ }^{1,2}$

email: ekadharma1996@gmail.com

\begin{abstract}
This study aims to analyze the menus at Kori Restaurant \& Bar, Kuta - Bali in the period June - December 2019. The results of this analysis are one of the references in determining food products in facing the new order of life during the covid19 pandemic. The results of the menu analysis showed that the appetizer group (appetizer) with the category of plowhorse as many as 3 items, 4 items star, 2 items of dog and 1 item of puzzel. The menu in the salad dish group with the plowhorse category is 2 items, the star is 3 items and the puzzle is 1 item. The menu in the soup (soup) group with the category of plowhorse, star and dog each has 1 item. Main course menu (main dish) in the International sub-group with 2 items of plowhorse, 15 items of star, 2 items of dog and 1 item of puzzle. Hamburger sub-group with 1 item plowhorse category, 2 star items and 1 item puzzle. Main Course from Bali sub-group with 4 items plowhorse category, 3 star items, 1 dog item and 2 puzzle items. Menu in the dessert group with 2 items of plowhorse category, 6 star items, 1 item of dog and puzzle each. The decisions and follow-ups that will be taken are maintaining the menu, changing menu prices, improving menu positions or changing menus that can be made based on each category.
\end{abstract}

Keywords: engineering enu, food product determination strategy.

\section{PENDAHULUAN}

Coronavirus novel (Covid-19) merupakan sejenis virus yang mengakibatkan infeksi pneumonia yang sangat berbahya. Virus jenis ini akan mengakibatkan peradangan pada bronkus (saluran pernafasan) dan paru-paru. Virus covid-19 sudah menyebar dengan cepat di seluruh dunia, termasuk di Indonesia. Virus berbahaya ini sangat mudah menular, sehingga banyak negara mengambil beberapa kebijakan, dengan melarang warganya untuk bepergian antar kota/pulau/negara, tidak menerima kedatangan warga negara asing, menutup segala bentuk usaha yang berpotensi menimbulkan keramaian. Hal ini tentu saja akan memberikan pengaruh yang sangat buruk terhadap semua sektor pariwisata di Bali, karena tidak adanya tamu Mancanegara yang datang ke Bali. Wisatawan Nusantara pun sangat sedikit datang ke Bali, mengingat diberlakukannya PPKM (Pemberlakuan Pembatasan Kegiatan Masyarakat) dalam skala mikro maupun makro berdasarkan kebijakan 
Journal of Applied Management and Accounting Science. (JAMAS)

(Bagus Putu Ekadharma Susila, Surya Nugraha 14 - 27)

Vol 3, No 1, Desember 2021

Pemerintah Pusat dan daerah macam selera, karakter dan

setempat.

Pemerintah pusat melalui aparat kepemerintahan di daerah, menginstruksikan untuk mempercepat kegiatan vaksinasi secara nasional, termasuk masyarakat yang tinggal di Pulau Bali. Khusus untuk di Bali, hal ini bertujuan untuk mempercepat pemulihan pariwisata, dalam tatanan kehidupan baru (new normal). Adanya harapan yang semakin pasti dengan mulai dibukanya sektor pariwisata, mengakibatkan pelaku pariwisata melakukan berbagai perbaikan untuk menyesuaikan diri pada tatanan kehidupan baru. Perbaikan tersebut meliputi: perbaikan aset fisik, sistem, sumber daya manajemen dan lain sebagainya.

Restoran merupakan salah satu sektor pariwisata yang dikelola secara komersial dengan menyediakan layanan makanan dan minuman bagi setiap tamu yang datang ke tempat usahanya. Restoran didalam menjalankan usahanya, dapat berdiri sendiri (free standing restaurant), maupun bagian dari suatu hotel. Banyak restoran yang ada di Bali saat ini yang menawarkan beragamnya makanan dan minuman membuat para pelaku bisnis dibidang tersebut untuk menetapkan standar kualitas makanan dan minuman. Disamping untuk memberikan kualitas produk yang sama bagi setiap tamu, juga untuk mendapatkan keuntungan dari penjualan makanan dan minuman. Hal ini mengakibatkan setiap restoran akan menawarkan berbagai jenis makanan dan minuman yang disukai oleh tamu. Berbagai jenis makanan dan minuman yang dijual disuatu restoran akan ditawarkan ke pada tamu dalam bentuk menu. Tamu yang datang ke restoran memiliki berbagai kecendrungan (trend) yang sangat dinamis, akan memberikan pengaruh terhadap perkembangan makanan yang dijual. Perlunya proses analisis yang tepat dalam mengambil keputusan terhadap makanan yang dijual, merupakan salah satu strategi didalam mempertahankan atau meningkatkan loyalitas tamu sekaligus meningkatkan pendapatan atau keuntungan restoran. Hasil analisis dan keputusan yang diambil tentunya akan menjadi salah satu pertimbangan pelaku bisnis restoran untuk menghadapi persaingan pad tatanan kehidupan baru.

Berdasarkan hasil wawancara terhadap pihak menejemen dari Kori Restaurant\& Bar, Kuta - Bali, menyatakan bahwa pihak manajemen belum pernah melakukan evaluasi menu dengan cara rekayasa menu, dari awal buka sampai 2019. Pada tahun 2020, Kori Restaurant \& Bar, Kuta - Bali, sering tidak beoperasional karena himbauan pemerintah dan sepinya tamu yang datang. Menu biasanya akan diganti atau diubah berdasarkan

informasi dari pihak kepala dapur (chef) dengan harga jual berdasarkan besarnya prosentase keuntungan yang diinginkan. Hasil wawancara lainnya dengan pramusaji berdasarkan sudut pandang pribadi menyatakan terkadang ada makanan yang disukai oleh sebagian besar tamu, tetapi makanan tersebut dihapus dari menu. Hal tersebut tentunya menimbulkan pertanyaan dan mereka belum menemukan jawaban yang memuaskan. Perubahan menu yang dilakukan tentunya harus berdasrkan alasan yang kuat dari pihak manajemen sehingga tidak 
menimbulkan pertanyaan diantara karyawan.

Berdasarkan permasalahan yang telah diuraikan di atas, maka penulis tertarik untuk melakukan penelitian, dengan judul penelitian yaitu: "Меnu Engineering sebagai Strategi Penetapan Produk Makanan dalam Menghadapi Tatanan Kehidupan Baru di Kori Restaurant \& Bar, Kuta Bali, pada periode Bulan Juni Desember 2019.

\section{Rumusan Masalah}

Adapun permasalahan terkait dengan penelitian dapat dirumuskan sebagai berikut:

1. Bagaimanakah klasifikasi menu dengan pendekatan metode menu engineering di Kori Restaurant \& Bar, Kuta - Bali?

2. Bagaimanakah strategi penetapan produk makanan yang dilakukan di Kori Restaurant \& Bar, Kuta Bali?

\section{Tujuan Penelitian}

Adapun tujuan dalam melakukan penelitian ini adalah:

1. Untuk mengetahui klasifikasi menu dengan pendekatan metode menu engineering dalam menghadapi tatanan kehidupan baru di Kori Restaurant

2. Untuk mengetahui strategi penetapan produk makanandalam menghadapi tatanan kehidupan baru di Kori Restaurant

\section{Manfaat Penelitian} adalah:

Adapun manfaat penelitian ini

1. Sebagai informasi ilmiah tentang tentang menu makanan dan strategi dalam proses penetapan produk makan

2. Sebagai salah satu bahan kajian bagi pihak manjemen didalam merumuskan kebijakan penetapan produk makanan.

\section{TINJAUAN PUSTAKA \\ Pengertian Menu}

Menu (daftar makanan/ minuman) merupakan salah satu bagian yang sangat penting untuk sebuah restoran. Secara interenal menu sangat penting bagi setiap karyawan yang bekerja dan secara eksternal, menu merupakan sarana komunikasi dan promosi kepada tamu. Hal ini ditegaskan oleh Sudiara (1996), yang menyatakan bahwa fungsi dari menu adalah sebagai berikut:

1. Sebagai alat jual restoran

Menu berfungsi sebagai salah satu alat untuk menjual atau mempromosikan produk makanan/minuman di restoran kepada tamu

2. Sebagai alat penghubung antara produsen dan konsumen

Menu berisikan tentang gambaran yang dijelaskan secara singkat dan menarik tentang produk makanan/minuman di restoran, sehingga diharapkan menu mampu berfungsi sebagai ala/media penghubung antara produsen dan konsumen

3. Sebagai pedoman bagi karyawan dapur dalam mengolah makanan

Menu merupakan acuan bagi karyawan dapur (cook) didalam menyiapkan berbagai jenis makanan, sesuai dengan standar yang telah ditentukan

4. Sebagai pedoman dalam pembelian bahan baku makanan

Menu berfungsi sebagai pedoman bagi karyawan dapur untuk memesan bahan baku makanan berdasarkan kreteria/standar yang telah ditentukan kepada pihak pembelian barang (purchasing)

Berdasarkan fungsi menu tersebut maka menu merupakan daftar 
dari berbagai jenis makanan yang akan dijual di suatu restoran. Hal ini dipertegas oleh Kinton dan Caserani (dalam Sudiara, 2000), yang menyatakan bahwa menu adalah sebuah daftar makanan yang telah dilengkapi dengan harga masingmasing, yang disediakan dan ditampilkan untuk menarik pelanggan serta memberikan nilai terhadap sejumlah uang terhadap makanan yang ditawarkan. Mertayasa, (2012) yang menyatakan bahwa menu adalah daftar makanan yang disediakan kepada tamu untuk memudahkan tamu dalam berkomunikasi dan memilih makanan yang dipesannya. Berdasarkan pendapat tersebut di atas, maka dapat disimpulkan bahwa menu adalah daftar makanan yang telah dilengkapi dengan harga masingmasing, untuk memudahkan tamu dalam berkomunikasi dan memilih makanan yang dipesannya.

\section{Pengertian Menu Engineering}

Kasavana dan Smith (1982) dalam teorinya menyatakan bahwa "Menu engineering is a quantitative model design to provide a bisnis for analyzing a menu's success both in termis of attracting clientele and in terms of profitability". Adapun terjemahan bebasnya adalaha rekayasa menu merupakan desain model kuantitatif dalam kegiatan bisnis untuk menganalisis keberhasilan menu baik dalam hal menarik pelanggan maupun dalam hal profitabilitas. Menu engineering atau rekayasa menu pada dasarnya merupakan suatu metode untuk mengevaluasi menu secara keseluruhan dalam periode tertentu.

Sejumlah daftar makanan didalam sebuah menu yang ditawarkan kepada tamu, memiliki harga pokok (food cost) dengan harga jual (selling price) yang berbeda. Tamu yang datang ke suatu restoran akan memiliki keinginan, budget dan selera yang berbeda. Hal tersebut mengakibatkan tidak semua menu memiliki tingkat popularitas yang sama, sehingga setiap makanan akan memiliki tingkat penjualan dan tingkat keuntungan yang berbeda dalam periode tertentu. Ada 4 kemungkinan yang dapat terjadi, adalah:

1. Menu dengan tingkat penjualan dan tingkat keuntungan yang tinggi

2. Menu dengan tingkat penjualan dan tingkat keuntungan yang rendah

3. Menu yang memiliki tingkat penjualan yang tinggi namun memberikan tingkat keuntungan yang rendah

4. Menu yang memiliki tingkat penjualan rendah namun memberikan tingkat keuntungan yang tinggi.

Hasil analisis tersebut merupakan salah satu sumber didalam menentukan desain menu, pengambilan keputusan yang berlaku sekarang dan masa yang akan datang dan meningkatkan penjualan produk makanan yang paling popular dan menguntungkan. Kasavana dan Smith (1982) dalam teorinya juga menyatakan bahwa menu engineering atau rekayasa menu berpedoman pada 2 hal yaitu:

1. Menu Mix (MM) adalah hasil analisis tentang tingkat kegemaran tamu terhadap makanan yang terdapat didalam sebuah menu /tingkat popularitas makanan yang terdapat didalam sebuah menu

2. Contribution Margin (CM) adalah analisis tentang keuntungan kotor 
(gross profit) dari semua jenis makanan dalam menu

Sumber data yang dipergunakan untuk menentukan besarnya nilai pada Menu Mix (MM) dan Contribution Margin (CM), adalah:

1. Sales History untuk mendapatkan data Menu Mix

2. Standard Recipe untuk mendapatkan data Food Cost

3. Menu List untuk mendapatkan data Selling Price

\section{Tahapan Menu Engineering}

Kasavana (1984) dalam teorinya menyatakan bahwa secara garis besar terdapat 3 kelompok kegiatan dalam rekayasa menu (menu engineering):

1. Menentukan menu mix atau tingkat popularitas menu

2. Menentukan contribution margin /tingkat keuntungan kotor (gross profit) dari masing-masing menu

3. Keputusan dan tindak lanjut

$\mathrm{Ke}$ tiga kelompok kegiatan dalam rekayasa menu (menu engineering), kemudian dijabarkan menjadi 12 langkah/tahapan, yaitu:

1. Mengidentifikasikan jenis makanan

Jenis makanan diperoleh dari menu atau daftar makanan yang ditawarkan pada restoran tersebut. Semua jenis makanan (menu item) yang ditulis pada formulir analisis menu merupakan kelompok hidangan yang sama (Course): appetizer, Soup, Maincourse dan dessert

2. Mencatat jumlah porsi makanan yang terjual

Mencatat total jumlah makanan yang terjual untuk masing masing jenis makanan (menu item) dalam periode tertentu

3. Menghitung prosentase menu mix.
Menghitung besarnya prosentase menu mix dari setiap jenis makanan. Menentukan besarnya prosentase menu mix dilakukan dengan membagi jumlah makanan yang terjual dengan jumlah keseluruhan makanan yang terjual dalam satu kelompok hidangan, dikalikan dengan $100 \%$

Rumus:
MM\% $=$$\frac{\text { Menu Item Sold }}{\text { Total number sold }} 100 \%$

4. Menentukan kategori dari prosentase menu mix (MM\%)

Menentukan katagori dari prosentase menu mix (MM\%) masing - masing jenis makanan, yang dikategorikan menjadi High (Tinggi) atau Low (Rendah). Menentukan nilai rata - rata dari prosentase menu mix (AMM\%) dilakukan dengan satu dibagi dengan jumlah menu item yang terjual (N) dikalikan dengan $70 \%$.

Rumus:

$A M M \%=\frac{1}{N} \times 70 \%$

Adapun kreteria dalam menentukan katagori dari prosentase menu mix (MM\%) dari masing - masing jenis makanan, adalah:
a. $M M \% \geq$ Average $M M \%$ memiliki arti High (Tinggi)
b. $M M \%<$ Average $M M \%$ memiliki arti Low (Rendah)

5. Menentukan harga jual makanan Menulis harga jual dari masing masing jenis makanan

6. Menentukan harga pokok makanan.

Harga pokok makanan merupakan hasil penjumlahan dari Biaya resep baku, biaya garnish, Biaya makanan penyerta 
7. Menghitung Contribution Margin (CM) dari setip jenis makanan (menu item). Menentukan Contribution Margin (CM) dari setip jenis makanan (menu item) dilakukan dengan mengurangi harga jual (selling price) dengan harga pokok makanan (food cost).

Rumus:

8. $C M=$ Selling Price - Food Cost Menentukan Total Contribution $\operatorname{Margin}(C M)$.

Menentukan total Contribution Margin (Total CM) setiap jenis makanan (menu item) adalah Contribution Margin (CM) dari setip jenis makanan (menu item) dikalikan dengan item sold.

Rumus:

Total CM = CM Item $x$ Sold Item

9. Menghitung prosentase Contribution Margin (CM\%) dari setiap makanan.

Menghitung prosentase

Contribution Margin (CM\%) adalah Contribution Margin (CM) dari setiap makanan dibagi dengan total Contribution Margin (Total CM)

Rumus:

$$
C M \%=\frac{C M}{\text { Total } C M} \times 100 \%
$$

10. Menentukan Contribution Margin Category (CMC) dari masing - masing menu item yang dikategorikan menjadi High (Tinggi) atau Low (Rendah).

Menentukan
Margin Category $($ CMC) daribution
masing - masing menu item,
dilakukan dengan menentukan
nilai rata - rata
Margin (Average Contribution
Margin) dengan membagi total
Contribution Margin dengan total
menu sold.

Rumus

$$
A C M=\frac{\text { Total } C M}{\text { Total Item of Item Sold }}
$$

Adapun kreteria dalam menentukan Contribution Margin Category (CMC) dari masing masing jenis makanan, adalah:

a. $C M \% \geq$ Average $C M \%$ memiliki arti High

b. $C M \%<$ Average $C M \%$ memiliki arti Low

1. Menentukan klasifikasi menu item berdasarkan $M M \%$ category dan $C M$ category

Dilakuakan dengan membandingkan contribution margin masing - masing item dengan average contribution margin dan membandingkan menu mix percentage masing - masing item dengan average mепи mix percentage. Adapun kreteria dalam menentukan klasifikasi menu item dapat diuraikan pada tebel dibawah ini: 
Journal of Applied Management and Accounting Science. (JAMAS)

(Bagus Putu Ekadharma Susila, Surya Nugraha 14 - 27)

Vol 3, No 1, Desember 2021

\begin{tabular}{clll}
\hline \multicolumn{4}{c}{ Tabel 1 } \\
Kreteria dalam menentukan klasifikasi menu item \\
\hline $\begin{array}{c}\text { CM } \\
\text { Category }\end{array}$ & Category & \multicolumn{1}{c}{ Clasification } & \multicolumn{1}{c}{ Meaning } \\
\hline Low & High & Plowhorse /Margin I & Low profit, High popularity \\
High & High & Star/Winner/Margin II & High profit, High \\
Low & Low & Dog/Margin III & popularity \\
High & Low & Puzzel/Margin IV & High profit, Low popularity \\
\end{tabular}

Sumber: Kasavana \& Smith, 1982

Selain hasil analisis menu dapat diuraikan dalam bentuk diagram, dimana garis vertikal yang menunjukkan tingkat popularitas

(MM\%) dan garis horizontal menunjukkan tingkat keuntungan $(C M)$ seperti berikut:

\begin{tabular}{|l} 
Margin I \\
Plowhorse \\
L: Contribution Margin \\
H: Popularity \\
\\
\\
\\
L: Contribution Margin III \\
Dog \\
Lopularity
\end{tabular}

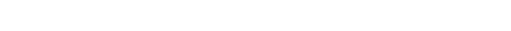$$
\sqrt{2}
$$$$
\text { Margin II }
$$

H: Contribution Margin

H: Popularity

$\mathrm{CM} \%$

Gambar 1.

Sumber: Kasavana, 1984

\section{Hasil analisis menu}
12. Menentukan Keputusan dan Tindak Lanjut
Keputusan yang diambil adalah mempertahankan menu, mengubah harga menu, memperbaiki posisi menu ataupun mengganti menu yang dapat dibuat berdasarkan klasifikasi sebagai berikut:

a. Plowhorse

Tindakan lanjut yang perlu diambil dari menu dengan kategori plowhorse yaitu:
1) Harus memperhatikan dengan hati-hti dalam menaikan harga jual
2) Posisi menu yang kurang harus disesuaikan dengan yang lain


3) Menggabungkan menu plowhorse dengan menu yang memiliki biaya makanan yang rendah sehingga dapat menaikkan CM.

4) Mempertimbangkan pengurangan porsi dari menu.

5) Mengganti menu dengan menu yang lebih menguntungkan

b. Winner/Star

Tindakan lanjut yang perlu diambil dari menu dengan kategori star disarankan untuk mengambil tindakan sebagai berikut:

1) Mempertahankan kualitas jumlah dan penyajian

2) Menempatkan menu pada tempat yang mudah dilihat

3) Mengatur elastisitas harga yang ditentukan

c. Dog

Dapat diartikan bahwa menu dengan kategori $d o g$ disarankan untuk mengambil tindakan sebagai berikut:

1) Menghapus kategori $d o g$ dari menu

2) Mengganti menu dog dengan menu yang memiliki permintaan dan keuntungan yang lebih besar

d. Puzzle

Dapat diartikan bahwa tindakan yang perlu diambil dari menu dengan kategory plowhorse yaitu:

1) Menghapus menu, terutama yang memiliki penjualan yang rendah

2) Menurunkan harga jual makanan
3) Menempatkan menu pada posisi yang strategis

4) Membatasi jumlah puzzle dalam menu sebab akan mempengaruhi permintaan para langganan

5) Mengganti nama makanan untuk mempengaruhi tingkat popularitasnya Hasil analisis menu akan dapat menjadi dasar bagi manajemen dalam menentukan tindakantindakan yang sesuai sehingga dapat dihasilkan menu yang digemari oleh tamu dan mampu meningkatkan keuntungan restoran.

\section{METODE PENELITIAN}

Metode pengumpulan data yang digunakan dalam penelitian ini adalah:

1. Observasi

Metode pengumpulan data, dengan melakukan pengamatan secara langsung ke objek penelitian

2. Wawancara

Metode wawancara cara pengumpulan data yang bertujuan untuk menggali informasi secara mendalam mengenai objek yang diteliti

3. Dokumentasi

Dokumen merupakan catatan peristiwa yang sudah berlalu. Dokumen biasanya berbentuk tulisan/gambar, seperti: mеnu, history of sales dan food cost.

4. Studi Kepustakaan

Mencari literatur dan informasi dari berbagai buku yang berhubungan dengan penelitian 


\section{HASIL DAN PEMBAHASAN}

Berdasarkan hasil menu analisis maka dapat diuraikan pada masing masing kelompok hidangan (course), dapat diuraikan sebagai berikut:
1. Appetizer (Hidangan Pembuka)

Hasil analisis menu pada kelompok hidangan appetizer (Hidangan Pembuka), maka dapat diuraikan pada tebel di bawah ini:

Tabel 2

Hasil Appetizer (Hidangan Pembuka)

\begin{tabular}{|c|c|c|c|c|c|c|c|c|c|c|c|}
\hline Menu Item & Sold & \begin{tabular}{|l|} 
Menu \\
Mix \% \\
$(\mathrm{MM} \%)$ \\
\end{tabular} & $\begin{array}{r}\text { Food } \\
\text { Cost } \\
(\mathrm{Rp}) \\
\end{array}$ & \begin{tabular}{|c|}
$\begin{array}{c}\text { Selling } \\
\text { Price } \\
(\mathrm{Rp})\end{array}$ \\
\end{tabular} & \begin{tabular}{|c|}
$\begin{array}{c}\text { Contribution } \\
\text { Margin } \\
(\mathrm{CM})\end{array}$ \\
\end{tabular} & $\begin{array}{l}\text { Menu } \\
\text { Cost } \\
\end{array}$ & $\begin{array}{c}\text { Menu } \\
\text { Revenue }\end{array}$ & $\begin{array}{l}\text { Menu } \\
\mathrm{CM}\end{array}$ & $\begin{array}{c}\text { CM } \\
\text { Category }\end{array}$ & $\begin{array}{c}\text { MM } \\
\text { Category } \\
\end{array}$ & $\begin{array}{c}\text { Menu } \\
\text { Item } \\
\text { Classification } \\
\end{array}$ \\
\hline Old Fashion Garlic Stick & 863 & $13,72 \%$ & 15.253 & 45.000 & 29.747 & 13163339 & 38835000 & 25671661 & $\mathrm{~L}$ & $\mathrm{H}$ & Plowhorse \\
\hline Mixed Bread Board & 491 & $7,80 \%$ & 23.030 & 50.000 & 26.970 & 11307730 & 24550000 & 13242270 & $\mathrm{~L}$ & $\mathrm{H}$ & Plowhorse \\
\hline Tuscan Sourdough Loaf & 135 & $2,15 \%$ & 20.045 & 50.000 & 29.955 & 2706075 & 6750000 & 4043925 & $\mathrm{~L}$ & $\mathrm{~L}$ & Dog \\
\hline Kori Focaccia and Dip & 952 & $15,13 \%$ & 19.520 & 55.000 & 35.480 & 18583040 & 52360000 & 33776960 & $\mathrm{H}$ & $\mathrm{H}$ & Star \\
\hline Char Grilled Bruschetta & 940 & $14,94 \%$ & 17.050 & 55.000 & 37.950 & 16027000 & 51700000 & 35673000 & $\mathrm{H}$ & $\mathrm{H}$ & Star \\
\hline Malai Koftas & 322 & $5,12 \%$ & 10.050 & 45.000 & 34.950 & 3236100 & 14490000 & 11253900 & $\mathrm{H}$ & $\mathrm{L}$ & Puzzel \\
\hline Chicken Betutu Spring Rolls & 248 & $3,94 \%$ & 24.750 & 55.000 & 30.250 & 6138000 & 13640000 & 7502000 & $\mathrm{~L}$ & $\mathrm{~L}$ & Dog \\
\hline Spice Homestyle Potato Wedges & 752 & $11,95 \%$ & 11.137 & 30.000 & 18.863 & 8375024 & 22560000 & 14184976 & $\mathrm{~L}$ & $\mathrm{H}$ & Plowhorse \\
\hline Kori Win Sum Basket & 683 & $10,86 \%$ & 29.755 & 75.000 & 45.245 & 20322665 & 51225000 & 30902335 & $\mathrm{H}$ & $\mathrm{H}$ & Star \\
\hline Calamari Ring & 906 & $14,40 \%$ & 22.050 & 55.000 & 32.950 & 19977300 & 49830000 & 29852700 & $\mathrm{H}$ & $\mathrm{H}$ & Star \\
\hline \multirow{2}{*}{$\begin{array}{c}\text { TOTAL } \\
\text { AVERAGE }\end{array}$} & 6.292 & $100 \%$ & 192.640 & & 119836273 & 325940000 & 206103727 & & & \\
\hline & & & & & & $36,77 \%$ & & & 32.756 & $7 \%$ & \\
\hline
\end{tabular}

Sumber: Data diolah

Tebel di atas, menunjukan bahwa katagori plowhorse sebanyak 3 item, yaitu: Old Fashion Garlic Stick, Mixed Bread Board dan Spice Homestyle Potato Wedges. Katagori star sebanyak 4 item, yaitu: Kori Focaccia \& Dip, Char Grilled Bruschetta, Kori Win Sum Basket dan Calamari Ring. Katagori dog sebanyak 2 item, yaitu: Tuscan Sourdough Loaf dan Chicken Betutu Spring Rolls. Katagori puzzel sebanyak 1 item, yaitu: Malai Koftas.

2. Salad

Hasil analisis menu pada kelompok hidangan salad, maka dapat diuraikan pada tebel di bawah ini:

Tabel 3

Hasil analisis menu hidangan salad

\begin{tabular}{|c|c|c|c|c|c|c|c|c|c|c|c|}
\hline Menu Item & Sold & $\begin{array}{l}\text { Menu } \\
\text { Mix \% } \\
(\text { MM\%) } \\
\end{array}$ & $\begin{array}{l}\text { Food } \\
\text { Cost } \\
\text { (Rp) } \\
\end{array}$ & \begin{tabular}{|c|} 
Selling \\
Price \\
(Rp) \\
\end{tabular} & \begin{tabular}{|c|} 
Contribution \\
Margin \\
(CM) \\
\end{tabular} & $\begin{array}{c}\text { Menu } \\
\text { Cost }\end{array}$ & $\begin{array}{c}\text { Menu } \\
\text { Revenue }\end{array}$ & $\begin{array}{l}\text { Menu } \\
\mathrm{CM}\end{array}$ & $\begin{array}{c}\mathrm{CM} \\
\text { Category }\end{array}$ & $\begin{array}{c}\text { MM } \\
\text { Category }\end{array}$ & \begin{tabular}{|c|} 
Menu \\
Item \\
Classification \\
\end{tabular} \\
\hline Fresh YellowFin Tuna Sashimi & 834 & $20,84 \%$ & 21.025 & 95.000 & 73.975 & 17534850 & 79230000 & 61695150 & $\mathrm{H}$ & $\mathrm{H}$ & Star \\
\hline Cajun Chicken Fillet Salad & 391 & $9,77 \%$ & 15.032 & 80.000 & 64.968 & 5877512 & 31280000 & 25402488 & $\mathrm{H}$ & $\mathrm{L}$ & Puzzel \\
\hline Classic Caesar Salad & 804 & $20,09 \%$ & 19.895 & 75.000 & 55.105 & 15995580 & 60300000 & 44304420 & $\mathrm{~L}$ & $\mathrm{H}$ & Plowhorse \\
\hline Grilled Squid & 543 & $13,57 \%$ & 20.478 & 95.000 & 74.522 & 11119554 & 51585000 & 40465446 & $\mathrm{H}$ & $\mathrm{H}$ & Star \\
\hline Thai Beef Salad & 746 & $18,65 \%$ & 30.073 & 95.000 & 64.927 & 22434458 & 70870000 & 48435542 & $\mathrm{H}$ & $\mathrm{H}$ & Star \\
\hline Avocado and Seafood Tian & 683 & $17,07 \%$ & 13.050 & 70.000 & 56.950 & 8913150 & 47810000 & 38896850 & $\mathrm{~L}$ & $\mathrm{H}$ & Plowhorse \\
\hline \multirow{2}{*}{$\begin{array}{c}\text { TOTAL } \\
\text { AVERAGE }\end{array}$} & 4.001 & $100 \%$ & 119.553 & & & 81875104 & 341075000 & 259199896 & & & \\
\hline & & & & & & $24,00 \%$ & & & 64.784 & 11,67 & \\
\hline
\end{tabular}

Sumber: Data diolah

Tebel di atas, menunjukan bahwa katagori plowhorse sebanyak 2 item, yaitu: Classic Caesar Salad dan Avocado and Seafood Tian. Katagori star sebanyak 3 item, yaitu: Fresh Yellow Fin Tuna
Sashimi, Grilled Squid dan Thai Beef Salad. Katagori puzzel sebanyak 1 item, yaitu: Cajun Chicken Fillet Salad. 
Journal of Applied Management and Accounting Science. (JAMAS)

(Bagus Putu Ekadharma Susila, Surya Nugraha 14 - 27)

Vol 3, No 1, Desember 2021

3. Soup (Sop)

Hasil analisis menu pada

maka dapat diuraikan pada tebel di

kelompok hidangan soup (sop),

Tabel 4

Hasil analisis menu Soup (Sop)

\begin{tabular}{|c|c|c|c|c|c|c|c|c|c|c|c|}
\hline Menu Item & Sold & \begin{tabular}{|l|} 
Menu \\
Mix \% \\
$($ MM\%) \\
\end{tabular} & $\begin{array}{l}\text { Food } \\
\text { Cost } \\
\text { (Rp) } \\
\end{array}$ & \begin{tabular}{|c|} 
Selling \\
Price \\
$(\mathrm{Rp})$ \\
\end{tabular} & \begin{tabular}{|c|}
$\begin{array}{c}\text { Contribution } \\
\text { Margin } \\
(\mathrm{CM})\end{array}$ \\
\end{tabular} & $\begin{array}{c}\text { Menu } \\
\text { Cost }\end{array}$ & $\begin{array}{c}\text { Menu } \\
\text { Revenue }\end{array}$ & $\begin{array}{c}\text { Menu } \\
\text { CM }\end{array}$ & $\begin{array}{c}\mathrm{CM} \\
\text { Category } \\
\end{array}$ & $\begin{array}{c}\text { MM } \\
\text { Category }\end{array}$ & $\begin{array}{c}\text { Menu } \\
\text { Item } \\
\text { Classification }\end{array}$ \\
\hline Tomato Creamy Soup & 734 & $32,92 \%$ & 18.470 & 40.000 & 21.530 & 13556980 & 29360000 & 15803020 & $\mathrm{~L}$ & $\mathrm{H}$ & Plowhorse \\
\hline Java Corn Soup & 491 & $22,03 \%$ & 18.805 & 40.000 & 21.195 & 9233255 & 19640000 & 10406745 & $\mathrm{~L}$ & $\mathrm{~L}$ & Dog \\
\hline Seafood Chowder & 1004 & $45,04 \%$ & 25.350 & 65.000 & 39.650 & 25451400 & 65260000 & 39808600 & $\mathrm{H}$ & $\mathrm{H}$ & Star \\
\hline TOTAL & 2.229 & $100 \%$ & 62.625 & & & 48241635 & 114260000 & 66018365 & & & \\
\hline AVERAGE & & & & & & $42,22 \%$ & & & 29.618 & 23,33 & \\
\hline
\end{tabular}

Sumber: Data diolah

Tebel di atas, menunjukan bahwa katagori plowhorse sebanyak 1 item, yaitu: Tomato Creamy Soup. Katagori star sebanyak 1 item, yaitu: Seafood Chowder. Katagori dog sebanyak 1 item, yaitu: Java Corn Soup.

4. Main Course (Hidangan Utama)
Main Course (Hidangan Utama) terdiri dari beberapa kelompok, Yaitu: sub kelompok hidangan International, Hamburger, Main Course from Bali dan pasta. Hasil analisis menu pada sub-kelompok International, dapat diuraikan pada tebel di bawah ini:

Tabel 5

Hasil analisis menu Main Course (Hidangan Utama)

\begin{tabular}{|c|c|c|c|c|c|c|c|c|c|c|c|}
\hline Menu Item & Sold & $\begin{array}{c}\text { Menu } \\
\text { Mix \% } \\
(\text { MM\%) }\end{array}$ & $\begin{array}{l}\text { Food } \\
\text { Cost } \\
\text { (Rp) }\end{array}$ & $\begin{array}{c}\text { Selling } \\
\text { Price } \\
\text { (Rp) }\end{array}$ & \begin{tabular}{|c|} 
Contribution \\
Margin \\
(CM)
\end{tabular} & $\begin{array}{l}\text { Menu } \\
\text { Cost }\end{array}$ & $\begin{array}{c}\text { Menu } \\
\text { Revenue }\end{array}$ & $\begin{array}{l}\text { Menu } \\
\text { CM }\end{array}$ & $\begin{array}{c}\text { CM } \\
\text { Category }\end{array}$ & $\begin{array}{c}\text { MM } \\
\text { Category }\end{array}$ & $\begin{array}{c}\text { Menu } \\
\text { Item } \\
\text { Classification }\end{array}$ \\
\hline Tasmanian Salmon & 753 & $6,23 \%$ & 25540 & 175.000 & 149.460 & 19231620 & 131775000 & 112543380 & $\mathrm{H}$ & $\mathrm{H}$ & Star \\
\hline Swordfish Steak & 515 & $426 \%$ & 20150 & 130.000 & 109.850 & 10377250 & 66950000 & 56572750 & $\mathrm{H}$ & $\mathrm{H}$ & Star \\
\hline Giant Hanging Seafood Grill & 963 & $797 \%$ & 31890 & 275.000 & 243.110 & 30710070 & 264825000 & 234114930 & $\mathrm{H}$ & $\mathrm{H}$ & Star \\
\hline Fresh Fillet of Barramundi & 678 & $5,61 \%$ & 20505 & 135.000 & 114.495 & 13902390 & 91530000 & 77627610 & $\mathrm{H}$ & $\mathrm{H}$ & Star \\
\hline Singapore Chili Crab & 929 & $7,69 \%$ & 29375 & 225.000 & 195.625 & 27289375 & 209025000 & 181735625 & $\mathrm{H}$ & $\mathrm{H}$ & Star \\
\hline Dory Fillet & 426 & $3,52 \%$ & 18146 & 115.000 & 96.854 & 7730196 & 48990000 & 41259804 & $\mathrm{H}$ & $\mathrm{H}$ & Star \\
\hline Fish and Chip & 590 & $6,09 \%$ & 12500 & 95.000 & 82.500 & 7375000 & 56050000 & 48675000 & $\mathrm{H}$ & $\mathrm{H}$ & Star \\
\hline Western Australian Sirloin & 821 & $6,79 \%$ & 27075 & 165.000 & 137.925 & 22228575 & 135465000 & 113236425 & $\mathrm{H}$ & $\mathrm{H}$ & Star \\
\hline Pork Schnitzel & 505 & $4,18 \%$ & 12.010 & 90.000 & 77.990 & 6065050 & 45450000 & 39384950 & $\mathrm{~L}$ & $\mathrm{H}$ & Plowhorse \\
\hline Chicken Fillet Cordon Bleu & 773 & $6,39 \%$ & 20100 & 115.000 & 94.900 & 15537300 & 88895000 & 73357700 & $\mathrm{H}$ & $\mathrm{H}$ & Star \\
\hline Char Grilled Chicken Breast & 492 & $4,07 \%$ & 15255 & 80.000 & 64.745 & 7505460 & 39360000 & 31854540 & $\mathrm{~L}$ & $\mathrm{H}$ & Plowhorse \\
\hline Medium Roasted Lamb Rump & 656 & $5,43 \%$ & 24090 & 185.000 & 160.910 & 15803040 & 121360000 & 105556960 & $\mathrm{H}$ & $\mathrm{H}$ & Star \\
\hline New Zealand Lamb Steak & 483 & $3,99 \%$ & 30355 & 265.000 & 234.645 & 14661465 & 127995000 & 113333535 & $\mathrm{H}$ & $\mathrm{H}$ & Star \\
\hline Giant Meaty Pork Ribs & 526 & $4,35 \%$ & 14780 & 170.000 & 155.220 & 7774280 & 89420000 & 81645720 & $\mathrm{H}$ & $\mathrm{H}$ & Star \\
\hline Thai Green Curry & 360 & $2,98 \%$ & 12350 & 80.000 & 67.650 & 4446000 & 28800000 & 24354000 & $\mathrm{~L}$ & $\mathrm{~L}$ & Dog \\
\hline Balinese Spice Pork Curry & 353 & $2,92 \%$ & 12325 & 98.000 & 85.675 & 4350725 & 34594000 & 30243275 & $\mathrm{H}$ & $\mathrm{L}$ & Puzzel \\
\hline Bombay Potato and Cauliflower Curry & 178 & $1,47 \%$ & 10100 & 70.000 & 59.900 & 1797800 & 12460000 & 10662200 & $\mathrm{~L}$ & $\mathrm{~L}$ & Dog \\
\hline Australian Prime Beef Fillet & 794 & $6,57 \%$ & 22355 & 185.000 & 162.645 & 17749870 & 146890000 & 129140130 & $\mathrm{H}$ & $\mathrm{H}$ & Star \\
\hline Tender Coconut Fed Pork Medallions & 555 & $5,59 \%$ & 15045 & 95.000 & 79.955 & 8349975 & 52725000 & 44375025 & $\mathrm{H}$ & $\mathrm{H}$ & Star \\
\hline Fresh Yellow Fin Tuna & 737 & $6,09 \%$ & 20100 & 120.000 & 99.900 & 14813700 & 88440000 & 73626300 & $\mathrm{H}$ & $\mathrm{H}$ & Star \\
\hline TOTAL & 12.087 & $100 \%$ & 394.046 & & & 257699141 & 1880999000 & 1623299859 & & & \\
\hline AVERAGE & & & & & & $13,70 \%$ & & & 79955 & $3,50 \%$ & \\
\hline
\end{tabular}

Sumber: Data diolah

Tebel di atas, menunjukan bahwa katagori plowhorse sebanyak 2 item, yaitu: Pork Schnitzel dan Char Grillof Chicken Breast. Katagori star sebanyak 15 item, yaitu: Tasmanian Salmon, Swordfish Steak, Giant Hanging Seafood Grill, Fresh Fillet of
Barramundi, Singapore Chili Crab, Dory Fillet, Fish and Chip, Western Australian Sirloin, Chicken Fillet Cordon Bleu, Medium Roasted Lamb Rump, New Zealand Lamb Steak, Giant Meaty Pork Ribs, Australian Prime Beef Fillet, Tender Coconut Fed Pork 
Journal of Applied Management and Accounting Science. (JAMAS)

(Bagus Putu Ekadharma Susila, Surya Nugraha 14 - 27)

Vol 3, No 1, Desember 2021

Medallions dan Fresh Yellow Fin

Tuna. Katagori dog sebanyak 2 item, yaitu: Thai Green Curry dan Bombay Potato and Green Curry.
Katagori puzzel sebanyak 1 item, yaitu: Balinese Spice Pork Curry. Hasil analisis menu pada kelompok hamburger, dapat diuraikan pada tebel di bawah ini:

Tabel 6

Hasil analisis menu pada kelompok hamburger

\begin{tabular}{|c|c|c|c|c|c|c|c|c|c|c|c|}
\hline Menu Item & Sold & $\begin{array}{l}\text { Menu } \\
\text { Mix \% } \\
\text { (MM\% }\end{array}$ & $\begin{array}{c}\text { Food } \\
\text { Cost } \\
\text { (Rp) }\end{array}$ & $\begin{array}{c}\text { Selling } \\
\text { Price } \\
(\mathrm{Rp})\end{array}$ & $\begin{array}{l}\text { Contribution } \\
\text { Margin } \\
(\mathrm{CM})\end{array}$ & $\begin{array}{c}\text { Menu } \\
\text { Cost }\end{array}$ & $\begin{array}{c}\text { Menu } \\
\text { Revenue }\end{array}$ & $\begin{array}{l}\text { Menu } \\
\mathrm{CM}\end{array}$ & $\begin{array}{c}\text { CM } \\
\text { Category }\end{array}$ & $\begin{array}{c}\text { MM } \\
\text { Category }\end{array}$ & \begin{tabular}{|c|} 
Menu \\
Item \\
Classification \\
\end{tabular} \\
\hline American Burger & 1270 & $35,94 \%$ & 9050 & 85.000 & 75.950 & 11493500 & 107950000 & 96456500 & $\mathrm{~L}$ & $\mathrm{H}$ & Plowhorse \\
\hline Bacon and Cheese Burger & 1093 & $30,93 \%$ & 10600 & 90.000 & 79.400 & 11585800 & 98370000 & 86784200 & $\mathrm{H}$ & $\mathrm{H}$ & Star \\
\hline The Aussie Jumbo with the Lot & 993 & $28,1 \%$ & 15700 & 95.000 & 79.300 & 15590100 & 94335000 & 78744900 & $\mathrm{H}$ & $\mathrm{H}$ & Star \\
\hline Australian Carpet Burger & 178 & $5,04 \%$ & 57500 & 160.000 & 102.500 & 10235000 & 28480000 & 18245000 & $\mathrm{H}$ & $\mathrm{L}$ & Puzzel \\
\hline TOTAL & 3.534 & $100 \%$ & 92.850 & & & 48904400 & 329135000 & 280230600 & & & \\
\hline AVERAGE & & & & & & $14,86 \%$ & & & 79296 & $17,5 \%$ & \\
\hline
\end{tabular}

Sumber: Data diolah

Tebel di atas, menunjukan bahwa katagori plowhorse sebanyak 1 item, yaitu: American Burger. Katagori star sebanyak 2 item, yaitu: Bacon and Cheese Burger dan The Aussie Jumbo with The
Lot. Katagori puzzel sebanyak 1 item, yaitu: Australian Carpet Burger. Hasil analisis menu pada hidangan Main Course from Bali, maka dapat diuraikan pada tebel di bawah ini:

Tabel 7

Hasil analisis menu pada hidangan Main Course from Bali

\begin{tabular}{|c|c|c|c|c|c|c|c|c|c|c|c|}
\hline Menu Item & Sold & $\begin{array}{l}\text { Menu } \\
\text { Mix \% } \\
(\text { MM\%) } \\
\end{array}$ & $\begin{array}{l}\text { Food } \\
\text { Cost } \\
\text { (Rp) } \\
\end{array}$ & \begin{tabular}{|l|} 
Selling \\
Price \\
(Rp) \\
\end{tabular} & \begin{tabular}{|c|} 
Contribution \\
Margin \\
(CM) \\
\end{tabular} & $\begin{array}{c}\text { Menu } \\
\text { Cost }\end{array}$ & $\begin{array}{c}\text { Menu } \\
\text { Revenue }\end{array}$ & $\begin{array}{l}\text { Menu } \\
\text { CM }\end{array}$ & $\begin{array}{c}\mathrm{CM} \\
\text { Category }\end{array}$ & $\begin{array}{c}\text { MM } \\
\text { Category } \\
\end{array}$ & \begin{tabular}{|c|} 
Menu \\
Item \\
Classification
\end{tabular} \\
\hline Bakmi Goreng & 425 & $14,36 \%$ & 10100 & 80.000 & 69.900 & 4292500 & 34000000 & 29707500 & $\mathrm{~L}$ & $\mathrm{H}$ & Plowhorse \\
\hline Nasi Goreng & 459 & $15,51 \%$ & 15430 & 65.000 & 49.570 & 7082370 & 29835000 & 22752630 & $\mathrm{~L}$ & $\mathrm{H}$ & Plowhorse \\
\hline Bebek Goreng Bumbu Pedas & 137 & $4,63 \%$ & 27115 & 135.000 & 107.885 & 3714755 & 18495000 & 14780245 & $\mathrm{H}$ & $\mathrm{L}$ & Puzzel \\
\hline Semur Daging & 209 & $7,06 \%$ & 20450 & 105.000 & 84.550 & 4274050 & 21945000 & 17670950 & $\mathrm{~L}$ & $\mathrm{H}$ & Plowhorse \\
\hline Udang Goreng Mentega & 173 & $5,85 \%$ & 27550 & 215.000 & 187.450 & 4766150 & 37195000 & 32428850 & $\mathrm{H}$ & $\mathrm{L}$ & Puzzel \\
\hline Balinese Sate Lilit & 315 & $1065 \%$ & 15980 & 105.000 & 89.020 & 5033700 & 33075000 & 28041300 & $\mathrm{H}$ & $\mathrm{H}$ & Star \\
\hline Ikan Pepes & 123 & $4,16 \%$ & 20319 & 90.000 & 69.681 & 2499237 & 11070000 & 8570763 & $\mathrm{~L}$ & $\mathrm{~L}$ & Dog \\
\hline Beef Sate & 353 & $11,93 \%$ & 22330 & 135.000 & 112.670 & 7882490 & 47655000 & 39772510 & $\mathrm{H}$ & $\mathrm{H}$ & Star \\
\hline Mixed Sate & 464 & $15,68 \%$ & 15315 & 105.000 & 89.685 & 7106160 & 48720000 & 41613840 & $\mathrm{H}$ & $\mathrm{H}$ & Star \\
\hline Chicken Sate & 301 & $10,17 \%$ & 12455 & 85.000 & 72.545 & 3748955 & 25585000 & 21836045 & $\mathrm{~L}$ & $\mathrm{H}$ & Plowhorse \\
\hline \multirow{2}{*}{$\begin{array}{c}\text { TOTAL } \\
\text { AVERAGE }\end{array}$} & 2.959 & $100 \%$ & 187.044 & & & 50400367 & 307575000 & 257174633 & & & \\
\hline & & & & & & $20,26 \%$ & & & 86.913 & $7 \%$ & \\
\hline
\end{tabular}

Sumber: Data diolah

Tebel di atas, menunjukan bahwa katagori plowhorse sebanyak 4 item, yaitu: Bakmi Goreng, Nasi Goreng, Semur Daging dan Chicken Sate. Katagori star sebanyak 3 item, yaitu: Balinese Sate Lilit, Beef Sate dan Mixed Sate. Katagori dog sebanyak 1 item: Ikan Pepes. Katagori puzzel sebanyak 2 item: Bebek Goreng
Bumbu Pedas dan Udang Goreng Mentega.

Hasil analisis menu pada kelompok pasta, dapat diuraikan pada tabel di bawah ini: 
Journal of Applied Management and Accounting Science. (JAMAS)

(Bagus Putu Ekadharma Susila, Surya Nugraha 14 - 27)

Vol 3, No 1, Desember 2021

\section{Tabel 8}

Hasil analisis menu pada kelompok pasta

\begin{tabular}{|c|c|c|c|c|c|c|c|c|c|c|c|}
\hline Menu Item & Sold & $\begin{array}{l}\text { Menu } \\
\text { Mix \% } \\
(\text { MM\%) } \\
\end{array}$ & $\begin{array}{r}\text { Food } \\
\text { Cost } \\
(\mathrm{Rp}) \\
\end{array}$ & \begin{tabular}{|l|} 
Selling \\
Price \\
$(\mathrm{Rp})$
\end{tabular} & $\begin{array}{c}\text { Contribution } \\
\text { Margin } \\
(\mathrm{CM})\end{array}$ & $\begin{array}{c}\text { Menu } \\
\text { Cost }\end{array}$ & $\begin{array}{c}\text { Menu } \\
\text { Revenue }\end{array}$ & $\begin{array}{c}\text { Menu } \\
\mathrm{CM}\end{array}$ & $\begin{array}{c}\mathrm{CM} \\
\text { Category }\end{array}$ & $\begin{array}{c}\text { MM } \\
\text { Category }\end{array}$ & \begin{tabular}{|c|} 
Menu \\
Item \\
Classification
\end{tabular} \\
\hline Spaghetti Rigate Napolitana & 415 & $19,07 \%$ & 13.937 & 75.000 & 61.063 & 5783855 & 31125000 & 25341145 & $\mathrm{~L}$ & $\mathrm{H}$ & Plowhorse \\
\hline Penne Rigate Napolitana & 398 & $18,29 \%$ & 14090 & 75.000 & 60.910 & 5607820 & 29850000 & 24242180 & $\mathrm{~L}$ & $\mathrm{H}$ & Plowhorse \\
\hline Penne Rigate Kori Style & 447 & $20,54 \%$ & 17500 & 85.000 & 67.500 & 7822500 & 37995000 & 30172500 & $\mathrm{H}$ & $\mathrm{H}$ & Star \\
\hline Spaghetti Rigate Marinara & 175 & $8,04 \%$ & 15000 & 85.000 & 70.000 & 2625000 & 14875000 & 12250000 & $\mathrm{H}$ & $\mathrm{L}$ & Puzzel \\
\hline Penne Rigate Marinara & 254 & $11,67 \%$ & 15000 & 85.000 & 70.000 & 3810000 & 21590000 & 17780000 & $\mathrm{H}$ & $\mathrm{H}$ & Star \\
\hline Spaghetti Bolognaise & 487 & $22,38 \%$ & 16050 & 90.000 & 73.950 & 7816350 & 43830000 & 36013650 & $\mathrm{H}$ & $\mathrm{H}$ & Star \\
\hline TOTAL & 2.176 & $100 \%$ & 91.577 & & & 33465525 & 179265000 & 145799475 & & & \\
\hline AVERAGE & & & & & & $18,67 \%$ & & & 67003 & $11,67 \%$ & \\
\hline
\end{tabular}

Sumber: Data diolah

Tebel di atas, menunjukan bahwa katagori plowhorse sebanyak 2 item, yaitu: Spaghetti Rigate Napolitana dan Penne Rigate Napolitana. Katagori star sebanyak 3 item, yaitu: Penne Rigate Kori Style, Penne Rigate Marinara dan Spaghetti
Bolognaise. Katagori puzzel sebanyak 1 item, yaitu: Spaghetti Rigate Marinara.

5. Side Order (Hidangan Penyerta)

Hasil analisis menu pada kelompok hidangan Side Order (Hidangan Penyerta), maka dapat diuraikan pada tebel di bawah ini:

Tabel 9

Hasil analisis menu pada kelompok hidangan Side Order (Hidangan Penyerta)

\begin{tabular}{|c|c|c|c|c|c|c|c|c|c|c|c|}
\hline Menu Item & Sold & \begin{tabular}{|l|} 
Menu \\
Mix \% \\
(MM\%)
\end{tabular} & $\begin{array}{l}\text { Food } \\
\text { Cost } \\
(\mathrm{Rp})\end{array}$ & $\begin{array}{c}\text { Selling } \\
\text { Price } \\
(\mathrm{Rp})\end{array}$ & $\begin{array}{l}\text { Contribution } \\
\text { Margin } \\
\text { (CM) }\end{array}$ & $\begin{array}{c}\text { Menu } \\
\text { Cost }\end{array}$ & $\begin{array}{c}\text { Menu } \\
\text { Revenue }\end{array}$ & $\begin{array}{c}\text { Menu } \\
\mathrm{CM}\end{array}$ & $\begin{array}{c}\mathrm{CM} \\
\text { Category }\end{array}$ & $\begin{array}{c}\text { MM } \\
\text { Category }\end{array}$ & $\begin{array}{c}\text { Menu } \\
\text { Item } \\
\text { Classification }\end{array}$ \\
\hline Bowl of French Fries & 378 & $38,89 \%$ & 8.100 & 40.000 & 31.900 & 3061800 & 15120000 & 12058200 & $\mathrm{H}$ & $\mathrm{H}$ & Star \\
\hline Tossed Salad & 195 & $20.06 \%$ & 11.015 & 55.000 & 43.985 & 2147925 & 10725000 & 8577075 & $\mathrm{H}$ & $\mathrm{H}$ & Star \\
\hline Mased Potatoes & 253 & $26,03 \%$ & 7.350 & 30.000 & 22.650 & 1859550 & 7590000 & 5730450 & $\mathrm{~L}$ & $\mathrm{H}$ & Plowhorse \\
\hline Steam Rice & 146 & $15,02 \%$ & 4.024 & 20.000 & 15.976 & 587504 & 2920000 & 2332496 & $\mathrm{~L}$ & $\mathrm{~L}$ & Dog \\
\hline TOTAL & 972 & $100 \%$ & 30.489 & & & 7656779 & 36355000 & 28698221 & & & \\
\hline AVERAGE & & & & & & $21,06 \%$ & & & 29.525 & $17,5 \%$ & \\
\hline
\end{tabular}

Sumber: Data diolah

Tebel di atas, menunjukan bahwa katagori plowhorse sebanyak 1 yaitu Mashed Potatoes. Katagori star sebanyak 2 yaitu Bowl of French Fries dan Tossed Salad. Katagori dog sebanyak 1 yaitu Steam Rice.

6. Dessert (Hidangan Penutup) Adapun hasil analisis menu pada kelompok hidangan dessert (hidangan penutup) dapat diuraikan pada table di bawah ini: 
Journal of Applied Management and Accounting Science. (JAMAS)

(Bagus Putu Ekadharma Susila, Surya Nugraha 14 - 27)

Vol 3, No 1, Desember 2021

\section{Tabel 10}

\section{Hasil analisis menu pada kelompok hidangan dessert (hidangan penutup)}

\begin{tabular}{|c|c|c|c|c|c|c|c|c|c|c|c|}
\hline Menu Item & Sold & $\begin{array}{c}\text { Menu } \\
\text { Mix \% } \\
\text { (MM\%) }\end{array}$ & $\begin{array}{r}\text { Food } \\
\text { Cost } \\
\text { (Rp) } \\
\end{array}$ & \begin{tabular}{|c|} 
Selling \\
Price \\
$(\mathrm{Rp})$ \\
\end{tabular} & $\begin{array}{c}\text { Contribution } \\
\text { Margin } \\
(\mathrm{CM})\end{array}$ & $\begin{array}{l}\text { Menu } \\
\text { Cost } \\
\end{array}$ & $\begin{array}{c}\text { Menu } \\
\text { Revenue }\end{array}$ & $\begin{array}{l}\text { Menu } \\
\mathrm{CM}\end{array}$ & \begin{tabular}{|c}
$\mathrm{CM}$ \\
Category \\
\end{tabular} & $\begin{array}{c}\text { MM } \\
\text { Category } \\
\end{array}$ & $\begin{array}{c}\text { Menu } \\
\text { Item } \\
\text { Classification }\end{array}$ \\
\hline Ice Cream and Brownie & 108 & 12,80 & 10.955 & 55.000 & 44.045 & 1183140 & 5940000 & 4756860 & $\mathrm{H}$ & $\mathrm{H}$ & Star \\
\hline Profiterole & 85 & 10,07 & 4.530 & 35.000 & 30.470 & 385050 & 2975000 & 2589950 & $\mathrm{~L}$ & $\mathrm{H}$ & Plowhorse \\
\hline Malang Apple Crumble & 83 & 9,83 & 8.924 & 50.000 & 41.076 & 740692 & 4150000 & 3409308 & $\mathrm{H}$ & $\mathrm{H}$ & Star \\
\hline Ice Cream & 116 & 13,74 & 4.525 & 35.000 & 30.475 & 524900 & 4060000 & 3535100 & $\mathrm{~L}$ & $\mathrm{H}$ & Plowhorse \\
\hline Fresh Tropical Fruits & 78 & 9,24 & 7.550 & 45.000 & 37.450 & 588900 & 3510000 & 2921100 & $\mathrm{H}$ & $\mathrm{H}$ & Star \\
\hline Kori's Choco Magma & 115 & 13,63 & 7.550 & 45.000 & 37.450 & 868250 & 5175000 & 4306750 & $\mathrm{H}$ & $\mathrm{H}$ & Star \\
\hline Sticky Toffee Date Pudding & 43 & 5,09 & 7.125 & 50.000 & 42.875 & 306375 & 2150000 & 1843625 & $\mathrm{H}$ & $\mathrm{L}$ & Puzzel \\
\hline Strawberry Crepes & 46 & 5,45 & 6.157 & 40.000 & 33.843 & 283222 & 1840000 & 1556778 & $\mathrm{~L}$ & $\mathrm{~L}$ & Dog \\
\hline Banana Split & 118 & 13,98 & 7.589 & 45.000 & 37.411 & 895502 & 5310000 & 4414498 & $\mathrm{H}$ & $\mathrm{H}$ & Star \\
\hline Cream Brulee & 92 & 10,90 & 9.763 & 50.000 & 40.237 & 898196 & 4600000 & 3701804 & $\mathrm{H}$ & $\mathrm{H}$ & Star \\
\hline \multirow{2}{*}{$\begin{array}{c}\text { TOTAL } \\
\text { AVERAGE }\end{array}$} & 884 & $100 \%$ & 74.668 & & & 6674227 & 39710000 & 33035773 & & & \\
\hline & & & & & & $16,81 \%$ & & & 37.371 & 11 & \\
\hline
\end{tabular}

Sumber: Data diolah

Tebel di atas, menunjukan bahwa menu dalam katagori plowhorse sebanyak 2 item, yaitu: Profiterole dan Ice Cream. Katagori star sebanyak 6 item, yaitu: Ice Cream and Brownie, Malang Apple Crumble, Fresh Tropical Fruits, Kori's Choco Magma, Banana Split dan Cream Brulee. Katagori dog sebanyak 1 item, yaitu: Strawberry Crepes. Katagori puzzel sebanyak 1 item, yaitu: Sticky Toffee Date Pudding.

Adapun keputusan dan tindak lanjut yang akan diambil adalah mempertahankan menu, mengubah harga menu, memperbaiki posisi menu ataupun mengganti menu yang dapat dibuat berdasarkan masing - masing katagori.

\section{SIMPULAN DAN SARAN Simpulan}

Berdasarkan hasil analisis dan pembahasan yang telah diuraikan dalam penelitian ini, maka dapat diperoleh simpulan, sebagai berikut:

1. Menu pada kelompok hidangan appetizer (hidangan pembuka) dengan katagori plowhorse sebanyak 3 item, star sebanyak 4 item, dog sebanyak 2 item dan puzzel sebanyak 1 item
2. Menu pada kelompok hidangan salad dengan katagori plowhorse sebanyak 2 item, star sebanyak 3 item dan puzzel sebanyak 1 item

3. Menu pada kelompok hidangan soup (sop) dengan katagori plowhorse, star dan dog masing masing sebanyak 1item

4. Menu hidangan main course (hidangan utama) pada kelompok International dengan katagori plowhorse sebanyak 2 item, star sebanyak 15 item, dog sebanyak 2 item dan puzzel sebanyak 1 item. Kelompok Hamburger dengan katagori plowhorse sebanyak 1 item, star sebanyak 2 item dan puzzel sebanyak 1 item. Kelompok Main Course from Bali dengan katagori plowhorse sebanyak 4 item, star sebanyak 3 item, dog sebanyak 1 item dan puzzel sebanyak 2 item

5. Menu pada kelompok hidangan dessert (hidangan penutup) dengan katagori plowhorse sebanyak 2 item, star sebanyak 6 item, dog dan puzzel masing - masing sebanyak 1 item

6. Adapun keputusan dan tindak lanjut yang akan diambil adalah dengan mempertahankan menu, mengubah harga menu, memperbaiki posisi menu ataupun 
mengganti menu berdasarkan

\section{Saran}

masing - masing katagori.

Adapun saran yang bisa

diajukan kepada pihak manajemen

Kori Restaurant \& Bar, Kuta - Bali adalah:

1. Perlu melakukan analisis menu secara berkesinambungan

2. Perlu melakukan kajian yang lebih mendalam mengenai tindak lanjut keputusan yang akan diambil

\section{DAFTAR PUSTAKA}

Kasavana ML, Smith DI. 1982. Menu engineering: A practical guide. Hospitality Publishers. Lancing (UK).

Kasavana ML. 1984. Computer System for Food Service Operation. Van Nostrand Reinhold. New York

Mertayasa, I Gede Agus . 2012. Food and Beverage Service Operational. Yogyakarta: Andi.

Sudiara. Bagus Putu. 1996. Food and Beverage Departement, Bali: BPLP. 